\title{
PRELIMINARY LOCATION AND GEOMETRY OF THE LAS VEGAS VALLEY SHEAR ZONE BASED ON GRAVITY AND AEROMAGNETIC DATA
}

\author{
By \\ V.E. Langenheim ${ }^{1}$, R.C. Jachens ${ }^{1}$, and K.M. Schmidt ${ }^{2}$
}

1997

Open-File Report 97-441

This report is preliminary and has not been reviewed for conformity with U.S. Geological Survey editorial standards or with the North American Stratigraphic Code. Any use of trade, firm or product names is for descriptive purposes only and does not imply endorsement by the U.S. Government.

${ }^{1}$ U.S. Geological Survey, MS 989, 345 Middlefield Rd., Menlo Park, CA 94025

${ }^{2}$ Department of Geological Sciences, Box 351310, University of Washington, Seattle, WA 98195 


\section{TABLE OF CONTENTS}

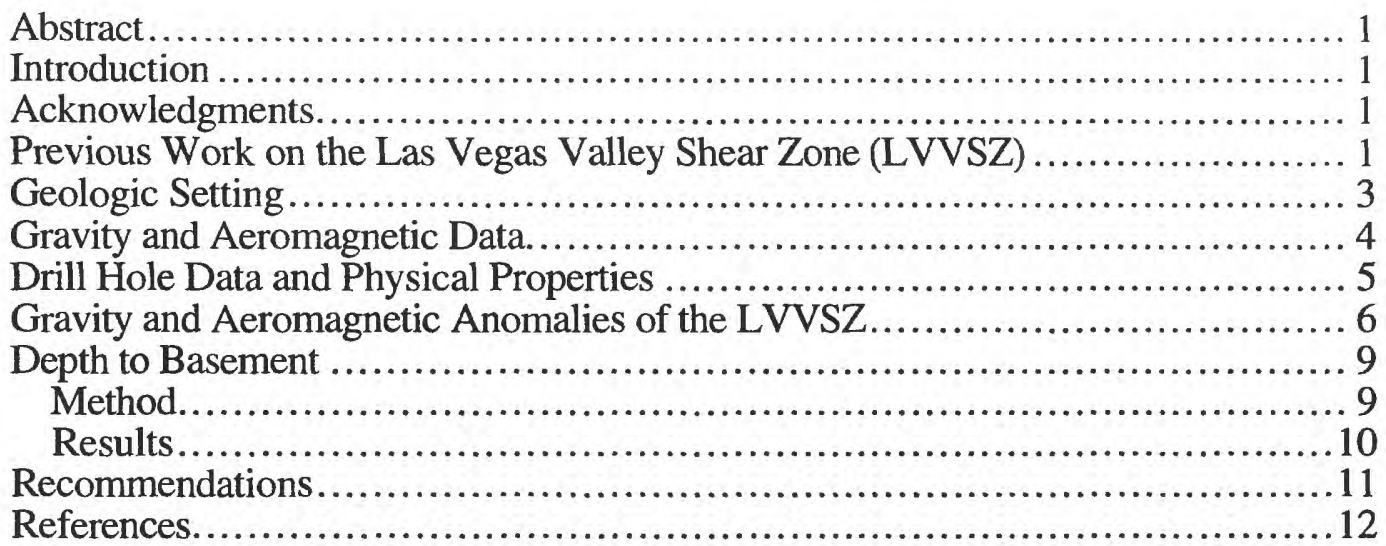

TABLES

Table 1. Densities and susceptibilities...................................... 15

Table 2. Density-depth functions .......................................... 16

\section{FIGURES}

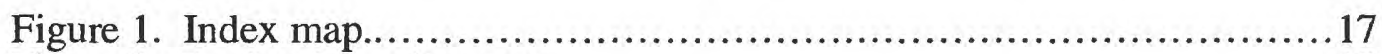

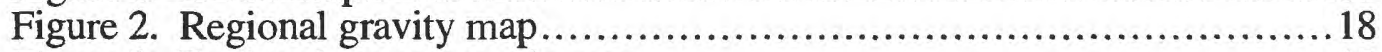

Figure 3. Regional aeromagnetic map.................................. 19

Figure 4. Regional density and magnetization boundaries......................2 20

Figure 5. Detailed gravity profiles across the LVVSZ .........................21

Figure 6. Two-dimensional gravity model .....................................22

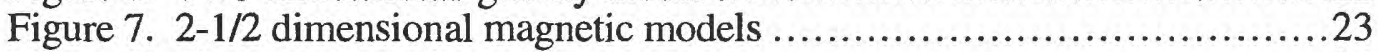

Figure 8a. Basement gravity map ..........................................24

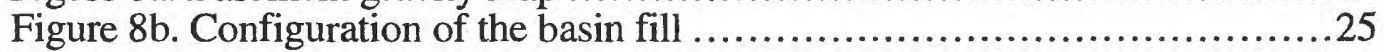




\begin{abstract}
The U.S. Geological Survey collected detailed gravity data in the northern part of the Las Vegas Valley to locate and characterize the Las Vegas Valley shear zone (LVVSZ). The LVVSZ has offset and flexed in a right-lateral sense the predominantly north-south trending mountain ranges of southern Nevada. Its exact location and geometry are poorly known, but most workers infer that it passes beneath Las Vegas Valley. A steep northwesttrending gravity gradient marks the northern margin of the basin beneath Las Vegas Valley. The basin margin probably coincides with significant faults of the shear zone. The gravity gradient is $2-3 \mathrm{~km}$ south of basement exposures of the Las Vegas and Arrow Canyon Ranges and extends as far east as Frenchman Mountain. East of Frenchman Mountain the gravity gradient apparently steps over about $5 \mathrm{~km}$ to the south and coincides with the northern edge of a strongly magnetic block beneath Frenchman Mountain. A 2-1/2 dimensional model based on the aeromagnetic data indicates that the edge of the block is vertical and probably does not extend deeper than $5 \mathrm{~km}$. The thickness of Cenozoic deposits based on an inversion of the gravity data indicates that the LVVSZ is also associated with a narrow, deep ( $>2 \mathrm{~km}$ ) basin north of Corn Creek Springs. The morphology of this basin is consistent with its having formed as a pull-apart basin.
\end{abstract}

\title{
Introduction
}

The U.S. Geological Survey conducted a detailed gravity study in the northern part of Las Vegas Valley to locate and characterize the Las Vegas Valley shear zone (LVVSZ). In order to determine the location of the shear zone, we applied filters to both gravity and aeromagnetic data. We also used a modified version of the iterative depth-to-basement calculation of Jachens and Moring (1990) to provide information on the nature of the basins associated with the LVVSZ. Additional gravity stations were collected in the area to provide regional coverage for these calculations.

\section{Acknowledgments}

Many thanks to the Las Vegas Valley Water District for providing support for this study. We also wish to thank Gary Dixon of the U.S. Geological Survey (USGS) for logistical support, Bruce Chuchel (USGS) for computer programming support, and Richard Blakely and John Grow (USGS) for reviews.

\section{Previous Work on Las Vegas Valley Shear Zone}

The Las Vegas Valley shear zone (LVVSZ) has offset the predominantly north-south trending mountain ranges of southern Nevada, bending them into large oroflexes (Fig. 1). Paleozoic isopachs, structural trends, and facies boundaries are also offset right-laterally across the LVVSZ (Stewart and others, 1968). The exact location of the LVVSZ is 
somewhat ambiguous. Longwell and others (1965) show the LVVSZ as a N60'Wtrending fault extending from northeast of Frenchman Mountain to Indian Springs. Campagna and Aydin (1994) instead show the LVVSZ as several N70 W strands stepping across Las Vegas Valley to a point south of Frenchman Mountain (Fig. 1). Using gravity data, they argue that the LVVSZ is responsible for creating deep ( $>1 \mathrm{~km}$ ) pull-apart basins beneath Las Vegas Valley. Lyles and Hess (1988) use isotope and ion geochemistry to delineate the LVVSZ; they indicate the shear zone trending more northerly ( $\left.\mathrm{N} 40^{\circ} \mathrm{W}\right)$ across the valley; however, the distribution of well and spring data could also support the more traditional location of the LVVSZ of Longwell and others (1965).

Longwell (1974) concluded that movement on the LVVSZ must have ended by the onset of deposition of the Muddy Creek Formation, as this unit is not cut by the shear zone. This observation and paleomagnetic and structural data bracket the principal period of movement along the LVVSZ between 14 and 8.5 Ma (Duebendorfer and Black, 1992). Displacement along the shear zone probably decreases to the east (Salyards and Shoemaker, 1987) and the LVVSZ cannot be traced east of Hamblin Mountain (Fig. 1). The LVVSZ may be cut by the left-lateral Lake Mead fault system, although detailed mapping of Tertiary sedimentary facies indicates that the LVVSZ and the Lake Mead fault system were active simultaneously during at least part of the Miocene (Bohannon, 1984). Estimates of total displacement on the LVVSZ from geologic data range from 23 to $69 \mathrm{~km}$ (Burchfiel, 1965; Stewart and others, 1968; Longwell, 1974; Wernicke and others, 1982); however, these estimates include as much as $44 \mathrm{~km}$ of additional bending. Matching basement gravity and aeromagnetic anomalies across the LVVSZ also indicate right-lateral offset along the LVVSZ (Langenheim and Jachens, in press). Pairing of aeromagnetic anomalies across the LVVSZ gives an estimate of $25 \mathrm{~km}$ of right-lateral offset whereas the pairing of the basement gravity anomalies suggest a maximum of $40 \mathrm{~km}$ offset. The aeromagnetic anomalies do not extend far enough away from the shear zone to give much information on the amount of bending and the control on the basement gravity field is only good enough to provide a maximum estimate of offset . Nonetheless, the estimates derived from matching aeromagnetic and basement gravity anomalies are thus consistent with estimates of discrete right-lateral offset along the LVVSZ of $23 \mathrm{~km}$ (Burchfiel, 1965).

The role of the shear zone and other strike-slip faults (such as the left-lateral Lake Mead strike-slip fault system) in the regional extension is controversial. Several workers (Guth, 1981, Wernicke and others, 1982; Duebendorfer and Black, 1992) believe that these strikeslip faults are accomodation structures that separate regions of differential extension. Ranges north of the shear zone, such as the Sheep and Desert Ranges, have undergone substantial extension (Guth, 1981; Guth and others, 1988), whereas the Spring Mountains, 
south of the shear zone, are essentially unaffected by extension (Burchfiel and others, 1974). Other workers, such as Ron and others (1986) and Campagna and Aydin (1994), argue that the strike-slip faults, such as the LVVSZ, are the dominant deformation mechanism in a given region.

\section{Geologic Setting}

For this study, basement rocks are defined as all pre-Cenozoic rocks. Basin deposits are defined to be Cenozoic. Basement rocks nearly ring Las Vegas Valley and are exposed in the Las Vegas and Desert Ranges, the Spring Mountains, and Frenchman Mountain (Fig. 1). The sequence exposed in the Spring Mountains consists of more than $7 \mathrm{~km}$ (23,000 ft) of Paleozoic sedimentary rock and approximately $1.2 \mathrm{~km}$ (4,000 ft) Mesozoic sedimentary rock (Longwell and others, 1965). Precambrian metamorphic and/or igneous rocks are inferred to underlie the Spring Mountains (Blank, 1987) on the basis of the stratigraphic section exposed at Frenchman Mountain (Fig. 1) and on the basis of the large gravity and magnetic anomalies present over the mountain range (Fig. 2 and 3). The structure of the Spring Mountains is very complex but, to first order, consists of a series of thrust faults, most probably of Mesozoic age, that are cut by Tertiary block faulting (Longwell and others, 1965).

In the Las Vegas Valley, basin fill consists of Tertiary and Quaternary sedimentary and volcanic rocks (Maxey and Jameson, 1948). Most of Las Vegas Valley is underlain by alluvial deposits; volcanic rocks are exposed only in the southern part of the valley (Fig. 1).

Volcanic rocks exposed in the River, McCullough, and Eldorado Mountains were erupted between 21 and $12 \mathrm{Ma}$ (Fig. 1; Anderson, 1971; Weber and Smith, 1987). Cenozoic volcanic units consist of andesitic and latitic lava flows and flow breccias and act as barriers to ground water movement from the valley fill south and east of Las Vegas Valley (Maxey and Jameson, 1948). Older Cenozoic sedimentary formations are generally well-consolidated and well-cemented and probably do not act as significant aquifers, although local interbedded gravel and sand lenses may be capable of transmitting sizable quantities of water, especially within the Muddy Creek Formation.

By far the most important aquifers in Las Vegas Valley reside within Pliocene and younger alluvial deposits. Faults offsetting these sediments are important barriers to ground water movement. Numerous faults are present within Las Vegas Valley (Bell, 1981). The origin of the faults is somewhat controversial; they may be tectonic in origin or may be a response to subsidence within the basin. Structures may also reside within the basement rocks; oil-well data and mapped structures in the pre-Cenozoic basement exposed 
west of Las Vegas Valley indicate a broad domal structure called the Arden dome (Miller, 1944; Longwell and others, 1965). However, this structure probably only affects preCenozoic units and thus would not affect the movement of groundwater within the basin.

\section{Gravity and Aeromagnetic Data}

548 gravity stations were collected with LaCoste \& Romberg gravity meters G-17C and G-614 during November 1996 and March 1997 to supplement regional gravity coverage (fig. 2; Kane and others, 1979; Langenheim and Jachens, 1996; Langenheim and Schmidt, 1996) and provide detailed data over the LVVSZ. The data were tied to a base station, LVGS, established in front of the U.S. Geological Survey office in Las Vegas. LVGS (latitude $36^{\circ} 4.02^{\prime} \mathrm{N}$; longitude $115^{\circ} 8.41^{\prime} \mathrm{W}$ ) has a value of $979593.62 \mathrm{mGal}$ based on ties to CPA, a gravity base station that is part of the Mt. Charleston calibration loop (Ponce and Oliver, 1981; observed gravity value of $979522.22 \mathrm{mGal}$ ).

Gravity data were reduced using the Geodetic Reference System of 1967 (International Union of Geodesy and Geophysics, 1971) and referenced to the International Gravity Standardization Net 1971 gravity datum (Morelli, 1974, p. 18). Gravity data were reduced to Bouguer anomalies using a reduction density of $2.67 \mathrm{~g} / \mathrm{cm}^{3}$. This includes corrections for earth-tide, instrument drift, elevation, latitude, and terrain. An additional isostatic correction using a sea-level crustal thickness of 16 miles $(25 \mathrm{~km})$, a crustal density of 2.67 $\mathrm{g} / \mathrm{cm}^{3}$, and a mantle-crust density contrast of $0.40 \mathrm{~g} / \mathrm{cm}^{3}$ was applied to the gravity data to remove long-wavelength gravitational effects of isostatic compensation of the crust due to topographic loading.

Horizontal control on the gravity station locations was provided by both surveying and by Rockwell PGLR Global Positioning System receivers. Station elevations along two detailed profiles were surveyed using an electronic-distance-measurement instrument. Other elevations were taken from spot elevations or interpolated from contours on the U.S. Geological Survey 7-1/2 minute series maps or estimated using altimetry. The uncertainty in the elevations of the surveyed stations is less than $0.3 \mathrm{~m}(1 \mathrm{ft})$. Uncertainties in the elevations derived from altimetry are about $3 \mathrm{~m}(10 \mathrm{ft})$, with a corresponding error in the reduced gravity values of less than $0.6 \mathrm{mGal}$. Stations with altimetry-determined elevations were confined to the mountainous regions of the study area.

Terrain corrections were computed to a radial distance of $167 \mathrm{~km}$ and involved a threepart process: (1) Hayford-Bowie zones A and B with an outer radius of $68 \mathrm{~m}$ were estimated in the field with the aid of tables and charts, (2) Hayford-Bowie zones C and D 
with an outer radius of $590 \mathrm{~m}$ were computed using 30-m digital elevation models, and (3) terrain corrections from a distance of $0.59 \mathrm{~km}$ to $167 \mathrm{~km}$ were calculated using a digital elevation model and a procedure by Plouff (1977). Total terrain corrections for the stations collected for this study ranged from 0.2 to $6.2 \mathrm{mGal}$, averaging $1.1 \mathrm{mGal}$. If the error resulting from the terrain correction is considered to be 5 to $10 \%$ of the total terrain correction, the largest error expected for the data is $0.6 \mathrm{mGal}$. However, the average error resulting from the terrain correction for the area of interest is small $(0.1 \mathrm{mGal})$.

Aeromagnetic data used to create Figure 3 consist of east-west flightlines from two separate surveys (U.S. Geological Survey, 1979, 1983). Both surveys were flown at 300 $\mathrm{m}(1000 \mathrm{ft})$ above ground along flightlines spaced $1.6 \mathrm{~km}$ (1 mile) apart. The data were adjusted to a common datum and then merged by smooth interpolation across a buffer zone along the survey boundaries (Saltus and Ponce, 1988).

To help delineate trends and gradients in the gravity field, we used a computer algorithm to locate the maximum horizontal gravity gradient (Blakely and Simpson, 1986; Fig. 4). Gradient maxima occur directly over vertical or near-vertical contacts that separate rocks of contrasting densities. We also calculated magnetization boundaries (Fig. 4) in the following way: First, in order to emphasize the edges of shallow magnetic sources, we filtered the aeromagnetic data by subtracting the upward contination of the aeromagnetic field from the actual data. Upward continuation is the transformation of aeromagnetic data measured on one suface to a higher surface; this operation tends to smooth the data by attenuation of short-wavelength anomalies (Blakely, 1995). We upward continued the data $100 \mathrm{~m}$. Subtraction of the upward-continued field from the original data results in highpass filtered, residual anomalies, thereby accentuating shallow sources. Second, the residual aeromagnetic field was mathematically transformed into pseudogravity anomalies (Baranov, 1957); this procedure effectively converts the magnetic field to the "gravity" field that would be produced if all the magnetic material were replaced by proportionately dense material. Third, the horizontal gradient of the pseudogravity field was calculated everywhere by numerical differentiation. Lastly, locations of the locally steepest horizontal gradient were determined by numerically searching for maxima in the horizontal gradient grid (Blakely and Simpson, 1986).

\section{Drill Hole Data and Physical Properties}

Although many wells have been drilled in Las Vegas Valley, only a handful have penetrated pre-Tertiary rock. Lintz (1957) and Longwell and others (1965) present limited drill log information for the wells. Plume (1989) shows the locations of wells that bottom 
in both pre-Cenozoic rock and alluvial deposits, but does not present stratigraphic information for the individual wells. Water wells in the western part of the valley give minimum thicknesses of 240-300 m of alluvium (Maxey and Jameson, 1948; Las Vegas Valley Water District logs, written commun., 1996).

Table 1 shows density measurements of hand samples of rocks from the area. Densities of volcanic rocks are not included; however, density measurements on volcanic rocks exposed south of the study area range from 2.27 to $2.58 \mathrm{~g} / \mathrm{cm}^{3}$ (Langenheim and Schmidt, 1996). Basement densities vary from 2.21 (gypsum-rich beds) to $2.94 \mathrm{~g} / \mathrm{cm}^{3}$. Mesozoic sedimentary rocks have an average density of $2.52 \mathrm{~g} / \mathrm{cm}^{3} ;$ Paleozoic sedimentary rocks have an average density of $2.63 \mathrm{~g} / \mathrm{cm}^{3}$.

Little information is available on the density of the alluvial deposits of Las Vegas Valley. One drill hole in Las Vegas Valley does provide information on porosity of the alluvial deposits there (Las Vegas Valley Water District, written commun., 1996; Langenheim and Jachens, 1996). Well logs indicate that the upper $174 \mathrm{~m} \mathrm{(570} \mathrm{ft)} \mathrm{of} \mathrm{alluvium} \mathrm{(primarily}$ gravel and sand) has an average porosity of $23 \%$. Below $174 \mathrm{~m}$, the alluvium has an average porosity of $15 \%$. Using the equations in Langenheim and Jachens (1996), the density of the alluvial deposits (as derived from the porosity data) is 2.08 and $2.30 \mathrm{~g} / \mathrm{cm}^{3}$, assuming that all the clasts have a density of $2.7 \mathrm{~g} / \mathrm{cm}^{3}$ and that the deposits are not saturated. If all the pores are filled with water, the bulk densities would be 2.31 and 2.45 $\mathrm{g} / \mathrm{cm}^{3}$, respectively.

Magnetic susceptibility data were also collected on hand samples. Sedimentary rocks are essentially nonmagnetic (Table 1). Susceptibilities of Precambrian schist exposed along the western edge of Frenchman Mountain range from 0.25 to $2.85 \times 10^{-3} \mathrm{cgs}$ units. Volcanic rocks exposed south of Las Vegas Valley (on the Kingman sheet) are characterized by variable susceptibilites, ranging from 0.00 to $0.92 \times 10^{-3} \mathrm{cgs}$ units (Langenheim and Schmidt, 1996). We do not have remanent magnetization measurements for these samples, but suspect that remanent magnetization could be a significant contribution to the total magnetization of some of the volcanic rocks exposed south of Las Vegas Valley.

\section{Gravity and Aeromagnetic Anomalies of the LVVSZ}

The northern strand of the LVVSZ as described by Campagna and Aydin (1994) coincides approximately with the northwest-trending gravity gradient marking the northern edge of the Las Vegas Valley gravity low (Fig. 2). The steep gradient south of Gass Peak 
is at least $30 \mathrm{~km}$ long. Two detailed gravity profiles across this steep gradient (Fig. 2; Fig. 5 ) indicate two inversion points where the horizontal gravity gradient is a local maximum. The northern maxima in horizontal gradient probably reflect the exposed edge of basement, although more gravity data north of the profiles are needed to examine the exact shape of the curve for modeling. 2-dimensional modeling confirms that the southern maxima mark the abrupt thickening of basin fill (Fig. 6).

The southeastern terminus of the steep gravity gradient appears to bend sharply to the southwest, on trend with the continuation of the northeast-trending gradient associated with the eastern edge of the Las Vegas Valley gravity low. The bend in the gradient also roughly coincides with the contact between alluvial deposits and Muddy Creek Formation (Longwell and others, 1965). A northwest-trending gravity gradient does continue eastward beyond the bend towards Gale Hills. It has the same trend as the northern edge of the Las Vegas Valley low, but is stepped over to the south by about $5 \mathrm{~km}$, along a line that parallels the northern margin of Frenchman Mountain. The polarity of the gradient has also changed from south-facing to north-facing.

The western terminus of the gravity gradient is more ambiguous. The steep gradient is absent along a northeast-trending profile about $7 \mathrm{~km}$ southeast of Corn Creek Springs (CC, Fig. 4). More gravity data are needed southeast of this profile in order to constrain the configuration of the gravity gradient in this area; however, it is clear from available data that the steep gradient south of Gass Peak does not extend uninterrupted to Corn Creek Springs. Corn Creek Springs is located on the extreme southeast corner of a narrow $(>10$ $\mathrm{km}$ wide), elongated gravity low that extends $20 \mathrm{~km}$ northwestward to Indian Springs. The southwestern margin of the low is marked by a steep gravity gradient, clearly delineated on Figure 4. The gradient is roughly on trend with the northwest projection of the steep gradient associated with the northern margin of Las Vegas Valley. The northeastern margin of the low is also marked by a gravity gradient, albeit less steep. The northeastern gradient coincides approximately with the Corn Creek Spring fault(s), with documented late Quaternary movement (Haynes, 1967; Quade, 1986). This gradient could also reflect another strand of the LVVSZ. The available gravity data do not indicate either of these gravity gradients extending west of Indian Springs.

The aeromagnetic data show a broad low (Fig. 3) paralleling the trend of the LVVSZ as defined by the gravity gradient. The edge of the sources of the magnetic highs over the Spring Mountains and Las Vegas Valley is at least $10 \mathrm{~km}$ south of the inferred location of the LVVSZ based on gravity. The lack of a magnetic signature of the LVVSZ across Las Vegas Valley is not surprising because the alluvial deposits of the basin and the Paleozoic sedimentary sequence exposed north of the LVVSZ are at most weakly magnetic. A weak 
magnetization boundary nonetheless does coincide with the location of the steep gravity gradient south of Gass Peak (Fig. 4). However, caution should be exercised in interpreting this boundary because the east-west survey flightlines cross the LVVSZ at a highly oblique angle, and the filtering process may have produced artifacts in the residual data.

North of Frenchman Mountain, the aeromagnetic data indicate a strong west-northwesttrending magnetization boundary. The intense aeromagnetic high over Frenchman Mountain appears to be truncated and elongated by a structure parallel to the LVVSZ. The magnetization boundary also coincides quite closely (within $1 \mathrm{~km}$ ) with a pronounced density boundary. The flightline direction makes it difficult to assess whether this magnetization boundary coincides exactly with the density boundary.

We created two 2 1/2 dimensional models (Fig. 7) using the program HYPERMAG (Saltus and Blakely, 1993) along a north-south tieline (Profile A-A'; Fig. 3) to ascertain the geometry of this boundary. We also show the gridded gravity data along the profile for comparison; we did not model the gravity because of lack of adequate gravity station coverage and because of possible 3-dimensional effects of crossing the bend in the steep gravity gradient (Fig. 2). The profile data indicate a pronounced aeromagnetic and gravity high over Frenchman Mountain. For the models, we assume that the source of the Frenchman Mountain anomaly extends $10 \mathrm{~km}$ to either side of the profile. The northern edge of the magnetic source is roughly in the same location as the northern edge of the density source. Model A assumes that the source of the magnetic high extends to depths of $12 \mathrm{~km}$; Model B assumes the source is no more than $5 \mathrm{~km}$ thick. Both models indicate that the top of the magnetic source is very shallow $(<1 \mathrm{~km})$ and that the northern edge of the source is vertical. Exposed Paleozoic and Mesozoic rocks do not account for the aeromagnetic high; possible sources for the high include Precambrian crystalline basement rocks, such as those exposed along the western edge of Frenchman Mountain, and Tertiary intrusive rocks. We prefer the first candidate because there is no evidence of contact metamorphism or extensive hydrothermal alteration in the exposed Frenchman Mountain sequence. We prefer Model B because (1) it fits the southern gradient of the Frenchman Mountain anomaly better and (2) the wrap-around of the aeromagnetic contours west of Frenchman Mountain (Fig. 3) indicates a shallow, somewhat thin source. The longwavelength gradient extending north of the low is probably caused by a deep source about $20 \mathrm{~km}$ north of Frenchman Mountain; this gradient continues at least $20 \mathrm{~km}$ to the northwest of where the Frenchman Mountain aeromagnetic anomaly appears truncated by a northeast-trending structure marking the eastern edge of the Las Vegas Valley basin. 


\section{Depth to Basement}

Method

We also calculated depth to basement to determine the configuration of the basins beneath Las Vegas Valley and therefore test the proposed geometry of the LVVSZ as proposed by Campagna and Aydin (1994). The method used in this study to estimate the thickness of Cenozoic rocks is an updated version of the iterative method developed by Jachens and Moring (1990) that incorporates drill hole and other geophysical data (Bruce Chuchel, U.S. Geological Survey, written commun., 1996). The method requires knowledge of the residual gravity field, of the exposed geology, and of the vertical density variation of the basin deposits. Drill holes that penetrate basement rock and geophysical data that provide constraints on the thickness of the basin fill can also be input into the model and provide useful constraints to the method as well as a test of the results. The method attempts to separate the gravity field into two components, that which is caused by variations of density within the pre-Cenozoic basement and that which is caused by variations of thickness of the Cenozoic basin fill. To accomplish this, the gravity data are separated into observations made on basement outcrops and observations made on Cenozoic deposits. The second set of observations is inverted to yield the thickness of Cenozoic deposits, based on an estimate of the density-depth function that characterizes the Cenozoic deposits. The inversion is complicated by two factors: (1) basement gravity stations are influenced by the gravity anomaly caused by low-density deposits in nearby basins, and (2) the basement gravity field varies because of density variations in the basement. The inversion presented here does not take into account lateral variations in the density distribution of the Cenozoic deposits.

To overcome these difficulties, a first approximation of the basement gravity field is determined by interpolating a smooth surface through all gravity values measured on basement outcrops. Basement gravity values are also calculated at locations where drill holes penetrated basement or other geophysical data constrain the basement surface, using the density-depth function. The basin gravity is then the difference between the observed gravity field on the original map and the first approximation of the basement gravity field and is used to calculate the first approximation of the thickness of Cenozoic deposits. The thickness is forced to zero where basement rock is exposed. This first approximation of the basement gravity is too low near basins because of the effects of the nearby low-density deposits on the basement stations. The basement gravity station values are "corrected" for the effects of the low-density deposits (the effects are calculated directly from the first approximation of the thickness of the Cenozoic deposits) and a second approximation of the basement gravity field is made by interpolating a smooth surface through the corrected 
basement gravity observations. This leads to an improved estimate of the basin gravity field, an improved depth to basement and a new correction to the basement gravity values. This procedure is repeated until successive iterations produce no significant changes in the basement gravity field.

\section{Results}

The model we created utilizes basement gravity stations and all available well and seismic data that constrain the thickness of Cenozoic fill. The model assumes a modified density-depth function derived from the porosities measured at well 78E in Las Vegas Valley (Table 2). The basement gravity field produced by the model (Fig. 8a) indicates high basement gravity values over Frenchman Mountain and Saddle Island where Precambrian rocks are exposed. Low basement gravity values coincide with exposures of Mesozoic sedimentary rocks (e.g. Gale Hills and area southwest of Lone Mountain). Only in the area of Corn Creek Springs and the area north of Frenchman Mountain do the basement gravity contours parallel the LVVSZ. Langenheim and Jachens (1997) correlated the basement gravity low over Lone Mountain with the basement gravity low over Gale Hills to estimate a maximum of $40 \mathrm{~km}$ of right-lateral offset along the LVVSZ.

The resulting distribution of basin sediments (Fig. $8 \mathrm{~b}$ ) indicates the deepest part of the basin is $5 \mathrm{~km}$ west of Frenchman Mountain and reaches thicknesses of more than $4 \mathrm{~km}$. This deep subbasin trends northeast, parallel to mapped scarps of the Frenchman Mountain fault system. The subbasin also has a part that trends northwest towards the center of the valley and parallels the gravity gradient along the southwest margin of Frenchman Mountain. The estimate of the thickness of basin fill in this area is strongly affected by the basement gravity high centered over Frenchman Mountain. The basement gravity high associated with Frenchman Mountain extends west into the basement according to our model (Fig. 8a). If this basement high is truncated by the structure controlling the eastern margin of the basin, then less sedimentary fill is required to produce the observed gravity low. For example, if the true basement gravity value just west of Frenchman Mountain is as low as $-8 \mathrm{mGal}$ (an extension of the basement gravity low at Lone Mountain), then the thickness of the basin fill does not exceed $2 \mathrm{~km}$.

The northern margin of the Las Vegas Valley basin is located about 2-3 km south of basement outcrops of the Las Vegas Range and Arrow Canyon Range. The basin fill along the LVVSZ in this area reaches thicknesses of at least $1 \mathrm{~km}$ at its western terminus to more than $2 \mathrm{~km}$ at its eastern terminus. This increase in thickness from west to east may be an artifact of the interpolation of the basement gravity field. Nonetheless, the LVVSZ appears to control the northern margin of the Las Vegas Valley basin. 
The character of the basin north of Corn Creek Springs is quite different from the basin configuration beneath Las Vegas Valley. Using the 1-km contour line as a guide, the Corn Creek Springs basin is very narrow, no more than $5 \mathrm{~km}$ wide, and elongated. Its morphology suggests a pull-apart origin (Campagna and Aydin, 1994). However, the basin beneath Las Vegas Valley is at least $10 \mathrm{~km}$ wide and more complex. This difference in basin morphology suggests that the basin beneath Las Vegas Valley may have had a more complicated structural history than the Corn Creek Springs basin. With the existing data, we cannot rule out a series of strike-slip faults stepping across Las Vegas Valley (Campagna and Aydin, 1994; Fig. 1); in fact, the deep, northwest-trending subbasin west of Frenchman Mountain (Fig. 8b) may be evidence for strike-slip motion under this part of the valley. However, the northeast-trending subbasin immediately west of Frenchman Mountain suggests that right-lateral strike-slip motion may not be the only mechanism for the formation of the Las Vegas valley basin.

\section{Recommendations}

Additional gravity data on basement exposures north of the LVVSZ would better constrain the basement gravity field and provide control for 2-1/2 dimensional gravity models across the shear zone. Additional gravity data at the western and eastern ends of the steep gravity gradient south of Gass Peak would also further constrain the configuration of the LVVSZ. A grid of gravity stations over the southern part of Las Vegas Valley may also help address whether the LVVSZ (or related structure) cuts across the valley as proposed by Campagna and Aydin (1994). Drill hole data and a better density-depth function also would refine the resulting basin configuration. Because our models are constrained only by basement gravity stations and a few limited well and seismic data, the basement gravity field over Las Vegas Valley cannot resolve basement gravity anomalies that have wavelengths less than the spacing between basement outcrops with gravity observations and wells (as much as $10 \mathrm{~km}$ across Las Vegas Valley). Drill hole data, particularly those wells that provide depths to basement rocks, could greatly improve the resolution of the basement gravity field. Other geophysical data, such as seismic reflection or refraction or electrical data, would also provide much needed, independent constraints on basin thickness. Seismic-reflection data would also provide information on the attitudes of the sedimentary fill and on possible structures affecting the fill. The density-depth function could be improved by borehole gravity surveys. Susceptibility measurements on rocks on Frenchman Mountain could help ascertain the source of the large aeromagnetic anomaly and its depth extent. Ground magnetic surveys across the LVVSZ south of Gass 
Peak could determine whether the magnetization boundaries derived from the filtered aeromagnetic data are artifacts of data processing or are real features within the fill.

\section{References}

Anderson, R.E., 1971, Thin skin distension in Tertiary rocks of southeastern Nevada: Geological Society of America Bulletin, v. 82, p. 42-58.

Baranov, V.I., 1957, A new method for interpretation of aeromagnetic maps: Pseudogravimetric anomalies: Geophysics, v. 22, p. 359-383.

Bell, J.W., 1981, Subsidence in Las Vegas Valley: Nevada Bureau of Mines and Geology Bulletin 95, 84 p., 1 plate, scale 1:62,500.

Blakely, R.J., 1995, Potential Theory in Gravity and Magnetic Applications: Cambridge University Press, Cambridge, England, 441 p.

Blakely, R.J., and Simpson, R.W., 1986, Approximating edges of source bodies from magnetic or gravity anomalies: Geophysics, v. 51, p. 1494-1498.

Blank, H.R., 1987, Role of regional aeromagnetic and gravity data in mineral-resource investigations, southeastern Nevada in USGS Research on Mineral Resources-1987, Third Annual V.E. McKelvey Forum on Mineral and Energy Resources, U.S. Geological Survey Circular 995, p. 5-6.

Bohannon, R.G., 1984, Nonmarine sedimentary rocks of Tertiary age in the Lake Mead region, southeastern Nevada and northwest Arizona: U.S. Geological Survey Professional Paper 1254, 72 p.

Burchfiel, B.C., 1965, Structural geology of the Specter Range quadrangle, Nevada and its regional significance: Geological Society of America Bulletin 76, p. 175-192.

Burchfiel, B.C., Fleck, R.J., Secor, T., Vincelette, R.R., and Davis, G.A., 1974, Geology of the Spring Mountains, Nevada: Geological Society of America Bulletin, v. 85 , p. $1013-1022$.

Campagna, D.J., and Aydin, Attila, 1994, Basin genesis associated with strike-slip faulting in the Basin and Range, southeastern Nevada: Tectonics, v. 13, no. 2, p. 327-341.

Duebendorfer, E.M., and Black, R.A., 1992, Kinematic role of transverse structures in continental extension: An example from the Las Vegas Valley shear zone, Nevada: Geology, v. 20, p. 1107-1110.

Guth, P.L., 1981, Tertiary extension north of the Las Vegas Valley shear zone, Sheep and Desert Ranges, Clark County, Nevada: Geological Society of America Bulletin, v. 92, p. 763-771.

Guth, P.L., Schmidt, D.L., Deibert, Jack, and Yount, J.C., 1988, Tertiary extensional basins of northwestern Clark County, Nevada, in Weide, D.L., and Faber, M.L., eds., This extended Land; Geological journeys in the southern Basin and Range, 
Geological Society of America Cordilleran Section Field Trip Guidebook: University of Nevada at Las Vegas Geosciences Department Special Publication 2, p. 239-253.

Haynes, C.V., 1967, Quaternary geology of the Tule Springs area, Clark County, Nevada, in Pleistocene Studies in Southern Nevada, Wormington, H.M, and Ellis, D., eds., Nevada State Museum of Anthropology Paper no. 13, p. 1-104.

International Union of Geodesy and Geophysics, 1971, Geodetic Reference System 1967: International Association of Geodesy Special Publication no. 3, $116 \mathrm{p}$.

Jachens, R.C., and Moring, B.C., 1990, Maps of the thickness of Cenozoic deposits and the isostatic residual gravity over basement for Nevada: U.S. Geological Survey Open-File Report 90-404, 15 p., 2 plates.

Kane, M.F., Healey, D.L., Peterson, D.L., Kaufmann, H.E., and Reidy, D., 1979, Bouguer gravity map of Nevada - Las Vegas sheet: Nevada Bureau of Mines and Geology Map 61, scale 1:250,000.

Langenheim, V.E., and Jachens, R.C., 1996, Thickness of Cenozoic deposits and groundwater storage capacity of the westernmost part of the Las Vegas Valley, inferred from gravity data: U.S. Geological Survey Open-File Report 96-259, 29 p.

Langenheim, V.E., and Jachens, R.C., in press, Structural Framework of the Las Vegas Valley, Nevada, as determined by gravity and aeromagnetic data: Nevada Bureau of Mines and Geology Special Publication.

Langenheim, V.E., and Schmidt, K.M., 1996, Thickness and storage capacity of basin fill of the northern part of the Eldorado Valley, Nevada, and the extent of the Boulder City pluton: U.S. Geological Survey Open-File Report 96-512, 27 p.

Lintz, Joseph, Jr., 1957, Nevada oil and gas drilling data, 1906-1953: Nevada Bureau of Mines and Geology Bulletin 52,80 p.

Longwell, C.R., 1974, Measure and date of movement on Las Vegas Valley shear zone, Clark County, Nevada: Geological Society of America Bulletin, v. 85, p. 985-990.

Longwell, C.R., Pampeyan, E.H., Bowyer, Ben, and Roberts, R.J., 1965, Geology and mineral deposits of Clark County, Nevada: Nevada Bureau of Mines and Geology Bulletin 62, 218 p.

Lyles, Brad E., and Hess, John W., 1988, Isotope and ion geochemistry in the vicinity of the Las Vegas Valley Shear Zone: Water Resources Center, Desert Research Institute, University of Nevada System Publication \#41111, 78 p.

Maxey, G.B., and Jameson, C.H., 1948, Geology and water resources of Las Vegas, Pahrump, and Indian Spring valleys, Clark and Nye Counties, Nevada: State of Nevada Office of the Engineer Water Resources Bulletin no. 5, 121 p. (+43 p. appendix), 6 sheets.

Miller, J.C., Report on geologic reconnaissance of the Arden area near Las Vegas, Clark Co., Nevada: U.S. Geological Survey Open-File Report no. 247, 16 p.

Morelli, C.(Ed.), 1974, The International Gravity Standardization Net, 1971: International Association of Geodesy Special Publication no. 4, 194 p. 
Plouff, Donald, 1977, Preliminary documentation for a FORTRAN program to compute gravity terrain corrections based on topography digitized on a geographic grid: U.S. Geological Survey Open-File Report 77-535, 45 p.

Plume, R.W., 1989, Ground-water conditions in Las Vegas Valley, Clark County, Nevada: U.S. Geological Survey Water-Supply Paper 2320-A, 15 p., 5 sheets.

Ponce, D.A., and Oliver, H.W., 1981, Charleston Peak gravity calibration loop, Nevada: U.S. Geological Survey Open-File Report 81-985, 20 p.

Quade, Jay, 1986, Late Quaternary environmental changes in the upper Las Vegas Valley, Nevada: Quaternary Research, v. 26, p. 340-357.

Ron, H., Nur, A., and Aydin, A., 1986, Strike-slip faulting and block rotation in the Lake Mead fault system: Geology, v. 14, p. 1020-1023.

Saltus, R.W., and Blakely, R.J., 1993, HYPERMAG-An interactive 2- and 2 1/2dimensional gravity and magnetic modeling program, Version 3.5: U.S. Geological Survey Open-File Report 93-287, 39 p.

Saltus, R.W., and Ponce, D.A., 1988, Aeromagnetic map of Nevada-Las Vegas sheet: Nevada Bureau of Mines and Geology Map 95, scale 1:250,000.

Salyards, S.L., and Shoemaker, E.M., 1987, Landslide and debris-flow deposits in the Thumb Member of the Miocene Horse Spring Formation on the east side of Frenchman Mountain, Nevada: A measure of basin-range extension: Geological Society of America Centennial Field Guide-Cordilleran section, p. 49-51.

Stewart, J.H., Albers, J.P., and Poole, F.G., 1968, Summary of regional evidence for right-lateral displacement in the western Great Basin: Geological Society of America Bulletin, v. 79, p. 1407-1414.

U.S. Geological Survey, 1979, Aeromagnetic map of southern Nevada: U.S. Geological Survey Open-File Report 79-1474, 1 sheet, scale 1:250,000.

U.S. Geological Survey, 1983, Aeromagnetic map of part of the Las Vegas $1^{\circ}$ by $2^{\circ}$ quadrangle, Nevada: U.S. Geological Survey Open-File Report 83-729, 1 sheet, scale $1: 250,000$.

Weber, M.E., and Smith, E.I., 1987, Structural and geochemical constraints on the reassembly of disrupted mid-Miocene volcanoes in the Lake Mead-Eldorado Valley area of southern Nevada: Geology, v. 15, no. 6, p. 553-6.

Wernicke, Brian, Spencer, J.E., Burchfiel, C.B., and Guth, P.L., 1982, Magnitude of crustal extension in the southern Great Basin: Geology, v. 10, no. 10, p. 499-502. 
Table 1. Densities, in $\mathrm{g} / \mathrm{cm}^{3}$ and susceptibilites $\left(10^{-3} \mathrm{cgs}\right.$ units)

Precambrian crystalline rocks

Sample Density Susceptibility

\begin{tabular}{llcl}
\hline $96146 \mathrm{a}$ & 2.92 & 0.25 & Precambrian schist \\
$96146 \mathrm{~b}$ & 2.94 & 2.85 & Precambrian schist \\
$96146 \mathrm{c}$ & 2.63 & 0.01 & Precambrian trondjemite
\end{tabular}

Mesozoic sedimentary rocks

$\begin{array}{lll}96121 & 2.21 & 0.00 \\ 96122 & 2.67 & 0.00 \\ 96123 & 2.62 & 0.00 \\ 96124 & 2.64 & 0.00 \\ 96124 \mathrm{r} & 2.60 & 0.00 \\ 96131 & 2.68 & 0.00 \\ 96001 \mathrm{r} & 2.50 & 0.00 \\ 96001 \mathrm{r} 2 & 2.44 & 0.00 \\ 96001 \mathrm{r} 3 & 2.45 & 0.00 \\ 96002 \mathrm{a} & 2.44 & 0.00 \\ 96002 \mathrm{~b} & 2.44 & 0.00 \\ 96004 & 2.49 & 0.00 \\ 96005 & 2.57 & 0.00\end{array}$

gypsiferous (Moenkopi) limestone (Moenkopi) sandstone (Moenkopi) calcareous (Moenkopi) limestone (Moenkopi) limestone (Moenkopi) Chinle Formation Chinle Formation Chinle Formation Aztec Sandstone Aztec Sandstone Aztec Sandstone Aztec Sandstone

Paleozoic sedimentary rocks

\begin{tabular}{lll}
\cline { 1 - 1 } 96001 & 2.58 & 0.00 \\
LV6054 & 2.58 & 0.00 \\
T004 & 2.72 & 0.00 \\
LV5001b & 2.65 & 0.00 \\
LV3010 & 2.68 & 0.00 \\
LV2018 & 2.69 & 0.00 \\
BDSE005 & 2.64 & 0.00 \\
BDNE016 & 2.62 & 0.00 \\
BDNE011 & 2.84 & 0.00 \\
96147 & 2.71 & 0.00 \\
LV5001a & 2.24 & 0.00 \\
96143 & 2.54 & 0.00 \\
97095 & 2.57 & 0.00 \\
97140 & 2.71 & 0.00 \\
97199 & 2.66 & 0.00 \\
$97255 \mathrm{r}$ & 2.66 & 0.00 \\
97328 & 2.64 & 0.00 \\
97345 & 2.62 & 0.00
\end{tabular}

Brecciated limestone (Kaibab) Brecciated limestone (Kaibab) Limestone (Kaibab) Limestone (Kaibab) Limestone (Kaibab) Limestone (Kaibab) Limestone (Kaibab) Limestone (Kaibab) Dolomite (Kaibab) Limestone (Kaibab) Fine-grained gypsum (Kaibab) Upper Cambrian limestone Siltstone (Bird Spring) Limestone (Bird Spring) Limestone (Bird Spring) Limestone (Bird Spring) Sultan Limestone Limestone (Bird Spring)

Cenozoic sedimentary rocks

\begin{tabular}{lll}
\hline 96154 & 2.63 & 0.00 \\
97274 & 2.15 & 0.00
\end{tabular}

Calcrete

Limestone (Muddy Creek) 
Table 2. Density-depth function*

\begin{tabular}{lll} 
Depth & \multicolumn{2}{c}{ Model } \\
Range & \multicolumn{2}{c}{ (Based on well 78E**) } \\
& sediments & volcanics \\
$0-200 \mathrm{~m}$ & -0.60 & -0.45 \\
$200-600 \mathrm{~m}$ & -0.40 & -0.40 \\
$\geq 600 \mathrm{~m}$ & -0.25 & -0.25 \\
\hline
\end{tabular}

*density contrast in $\mathrm{g} / \mathrm{cm}^{3}$.

**Las Vegas Valley Water District, written commun., 1996 


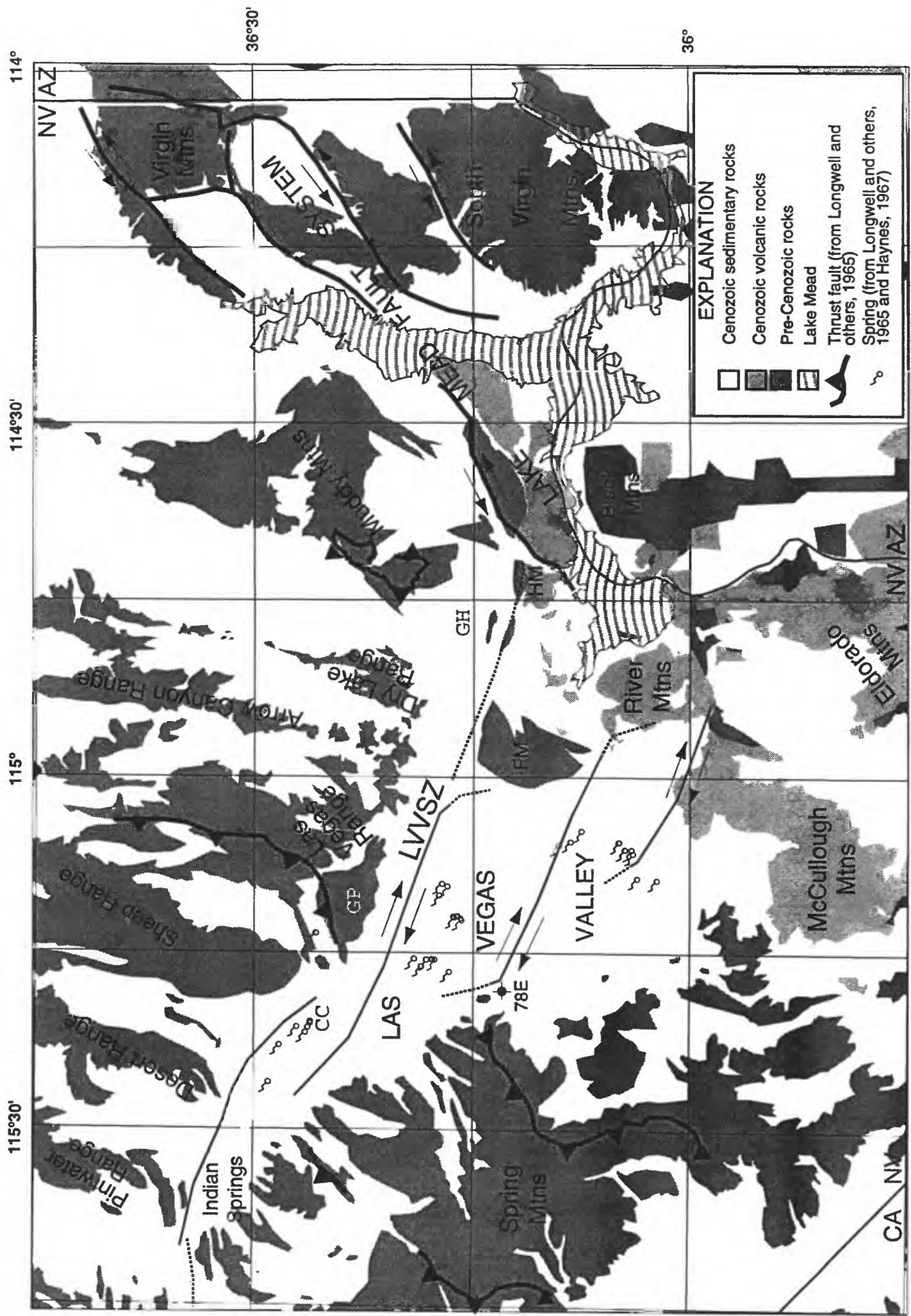

ஓั

등 들ㄹ

충

응 든

तั

ธ్ర

둥드음

을읃항

등응

U⿻口 \%

틍 응융

난

के.

드응무

N. ซำ

호응

들흥

은응 중

in N

రNणI

도

은

은

ㄷํㄷㅇ

তิ응용

ᄀ曲

\究응

己호 돈

๒ 동 잉

ํㅗㅇ

চ

동.

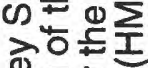

응 회든

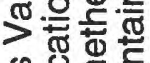

응

엉

>ㅎํ으

ส ㄷㅇ을

( )

든도

등ㄷㅇ응응

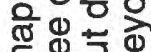

ह 닌응

ख

드원멍

-

๑)

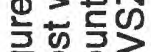
문을올 


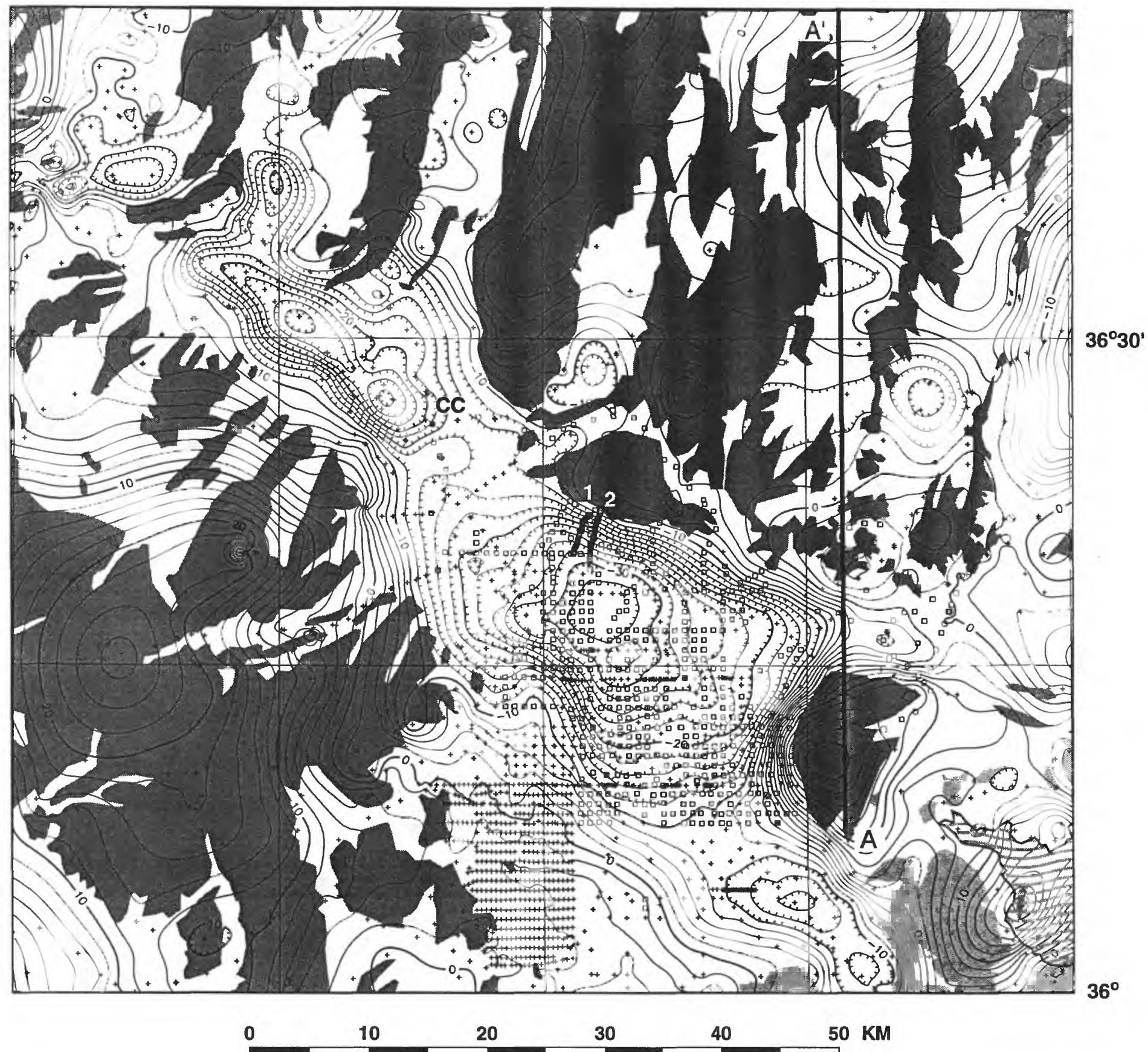

Figure 2. Isostatic gravity map of the Las Vegas Valley Shear Zone region. Contour interval, $2 \mathrm{mGal}$. See Figure 1 for explanation. Crosses show previous stations; boxes, new gravity stations. Detailed gravity profiles 1 and 2 are shown on Figure 5; profile A-A' is shown in Figure 6. CC, Corn Creek Springs. 


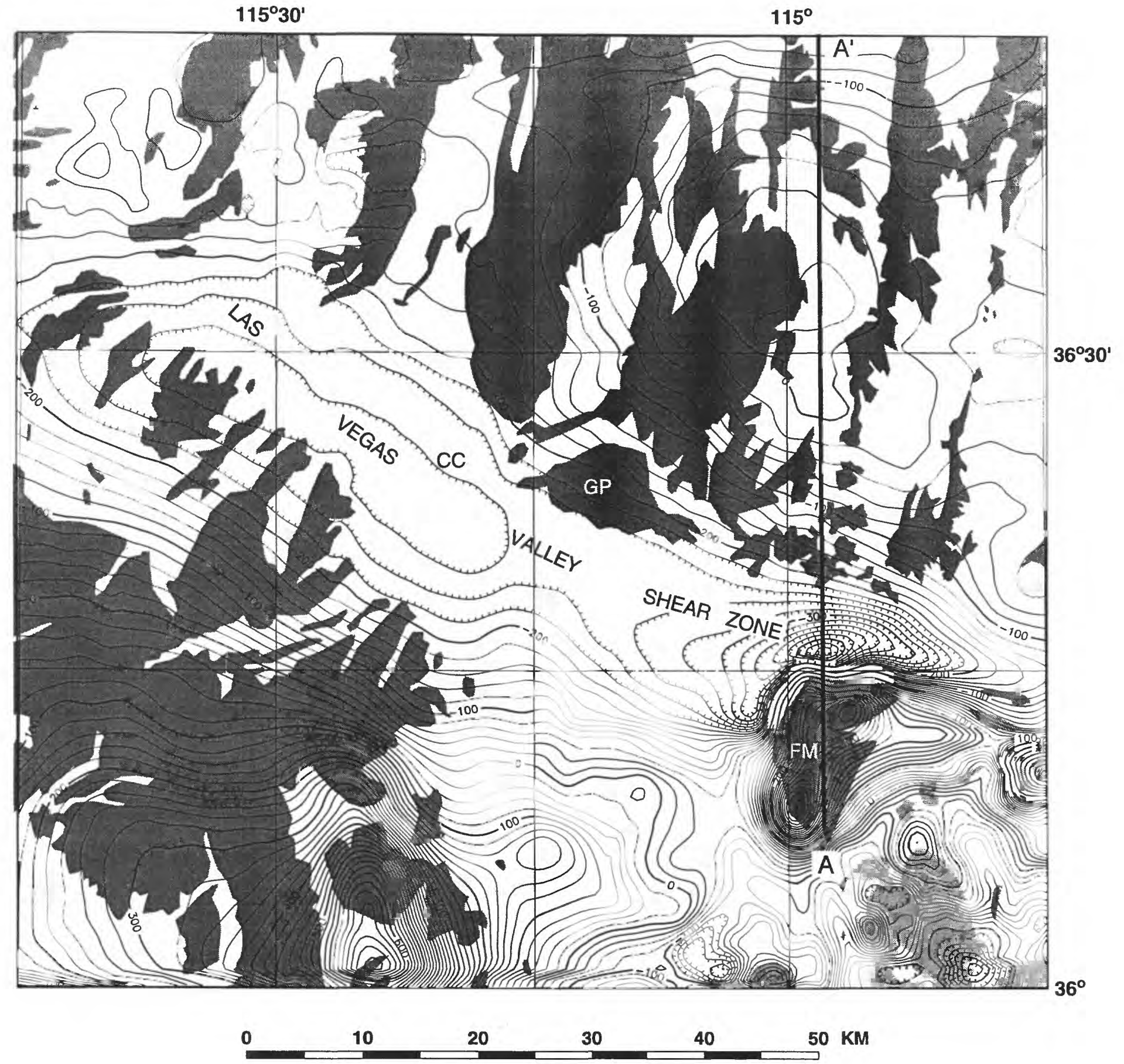

Figure 3. Aeromagnetic map of the Las Vegas Valley Shear Zone region. Contour interval, $20 \mathrm{nT}$. See Figure 1 for explanation of geology. 2-1/2 dimensional models of profile A-A' are shown in Figure 6. CC, Corn Creek Springs; FM, Frenchman Mountain; GP, Gass Peak. 


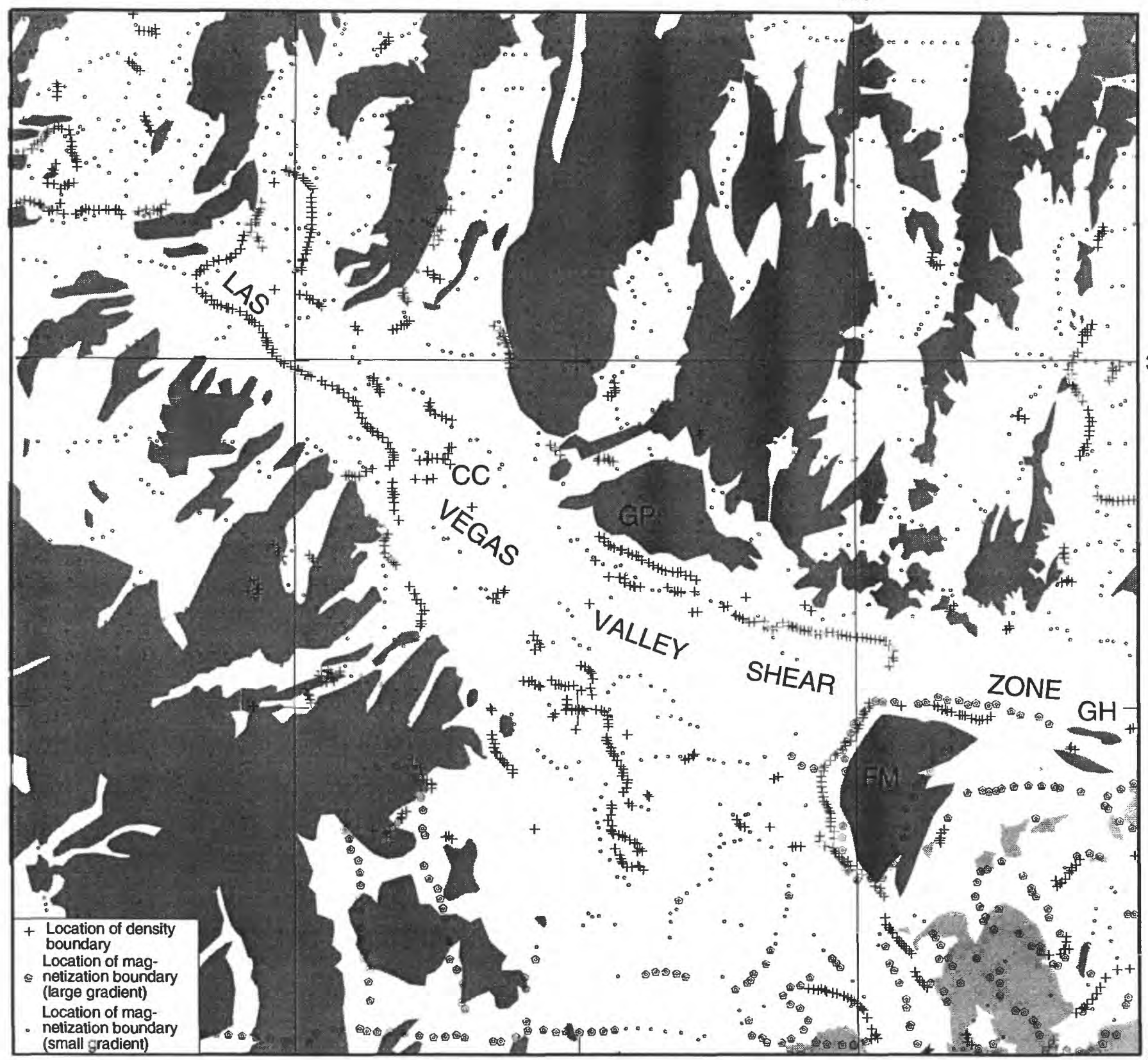

Figure 4. Locations of density and magnetization boundaries. CC, Corn Creek Springs; FM, Frenchman Mountain; GH, Gale Hills; GP, Gass Peak. 

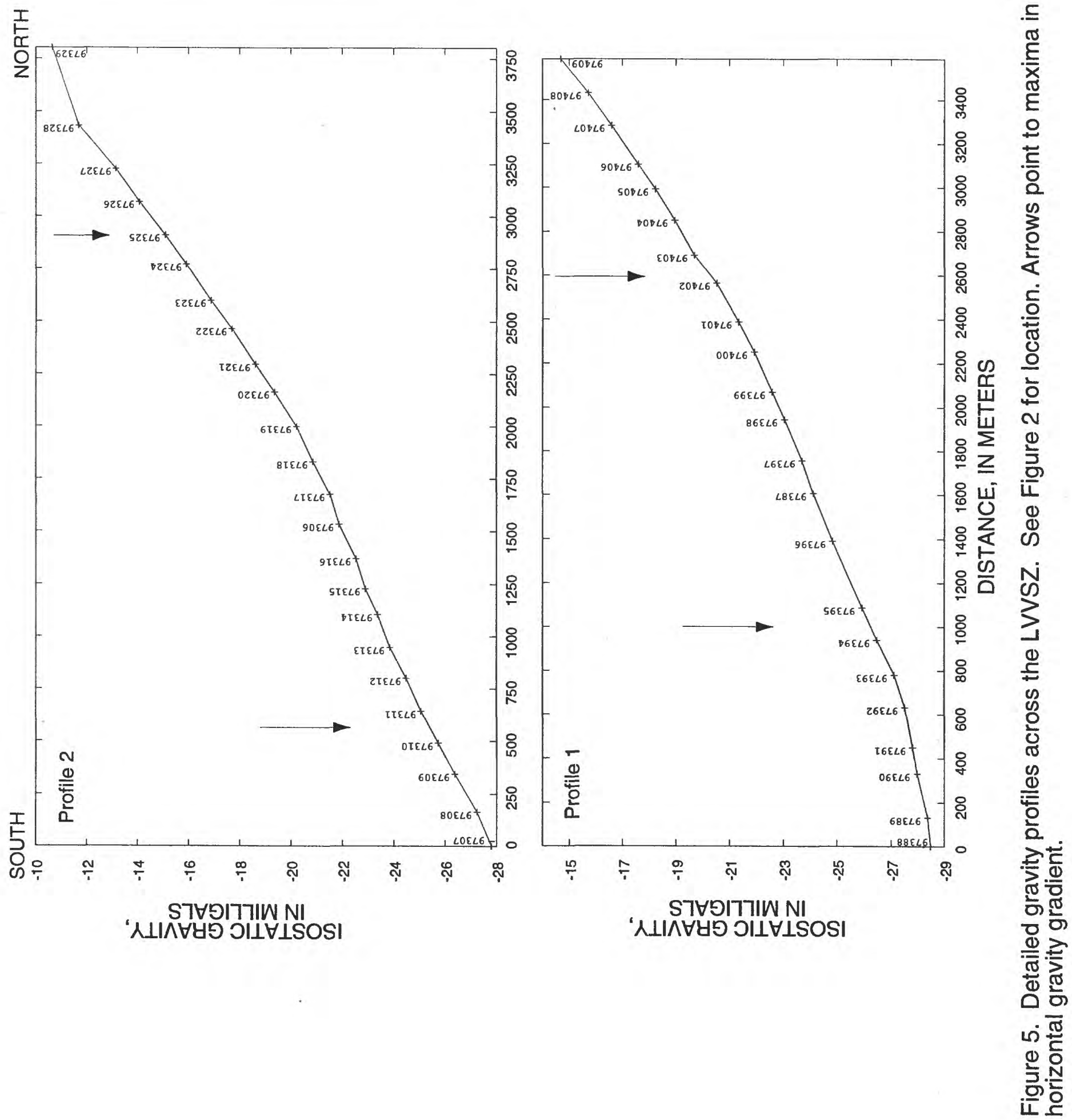
SOUTH

NORTH
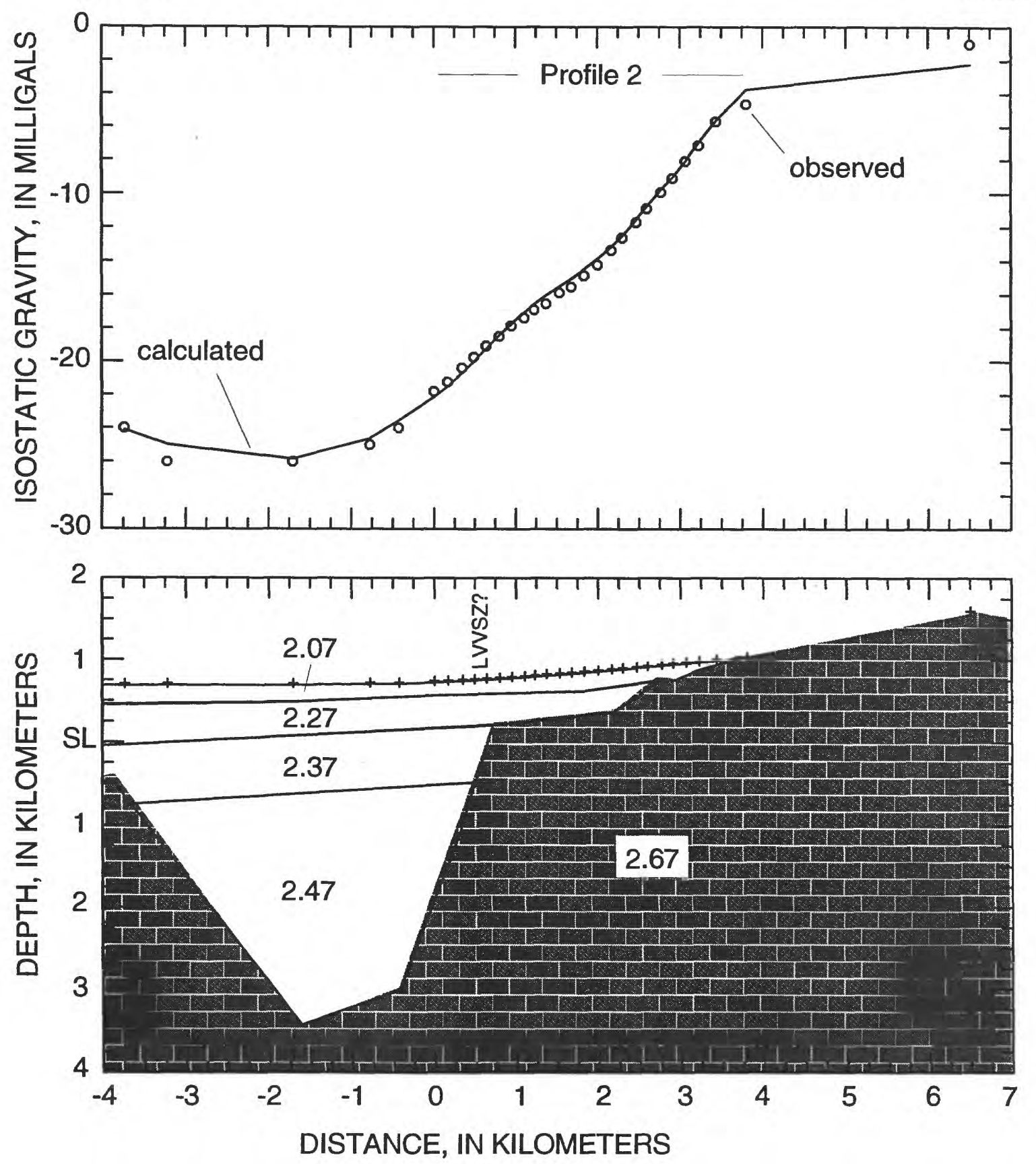

Figure 6. Two-dimensional gravity model along profile 2 (see Figure 2 and 5). Numbers on model are densities in $\mathrm{g} / \mathrm{cm}^{3}$. 


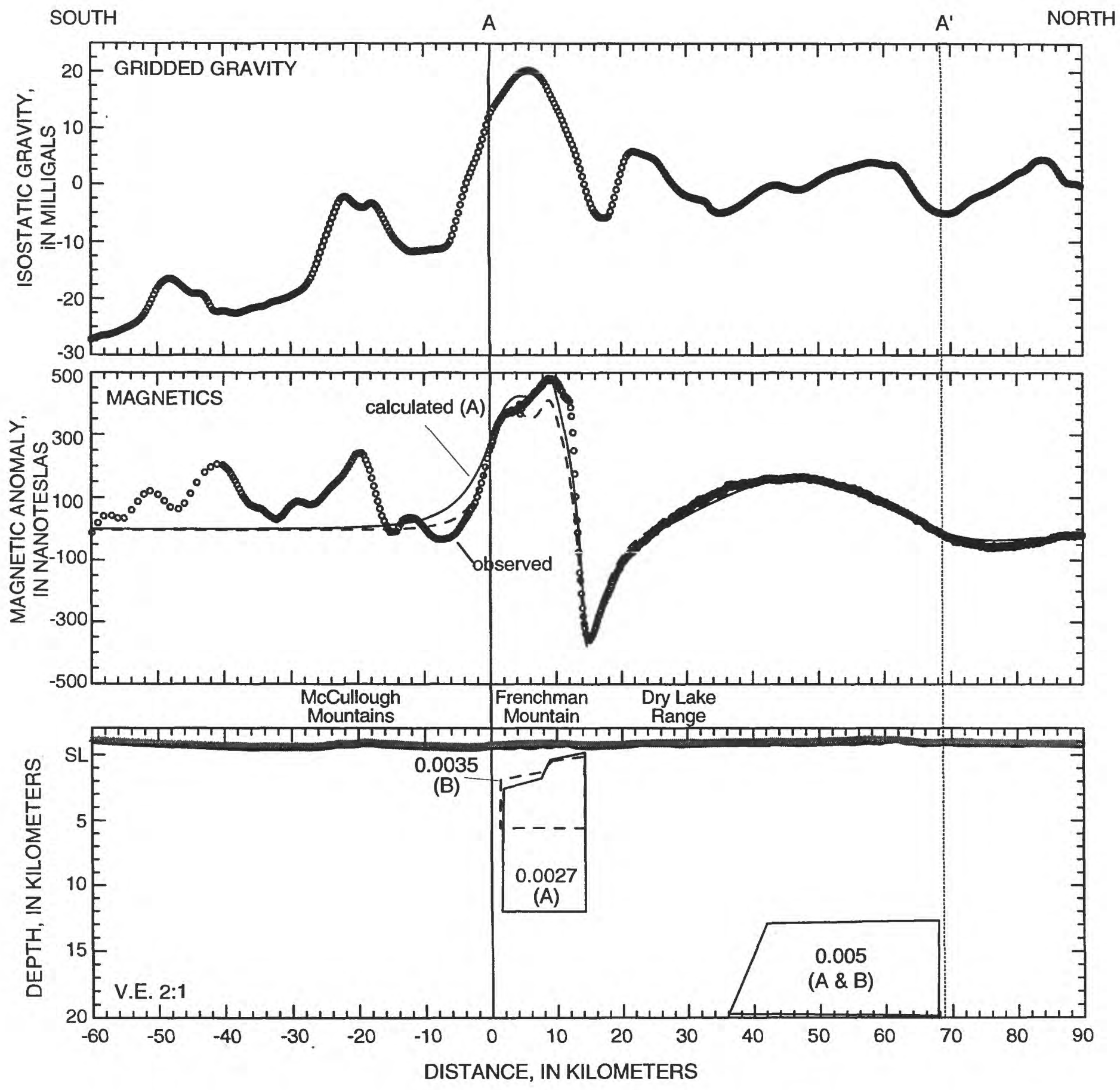

Figure 7. 2-1/2 dimensional magnetic models $A$ and $B$ (dashed outline) across extended profile A-A' and isostatic gravity data. Numbers in model are susceptibilities in cgs units. Thick gray line shows elevations of aeromagnetic profile; black line, topographic surface. 


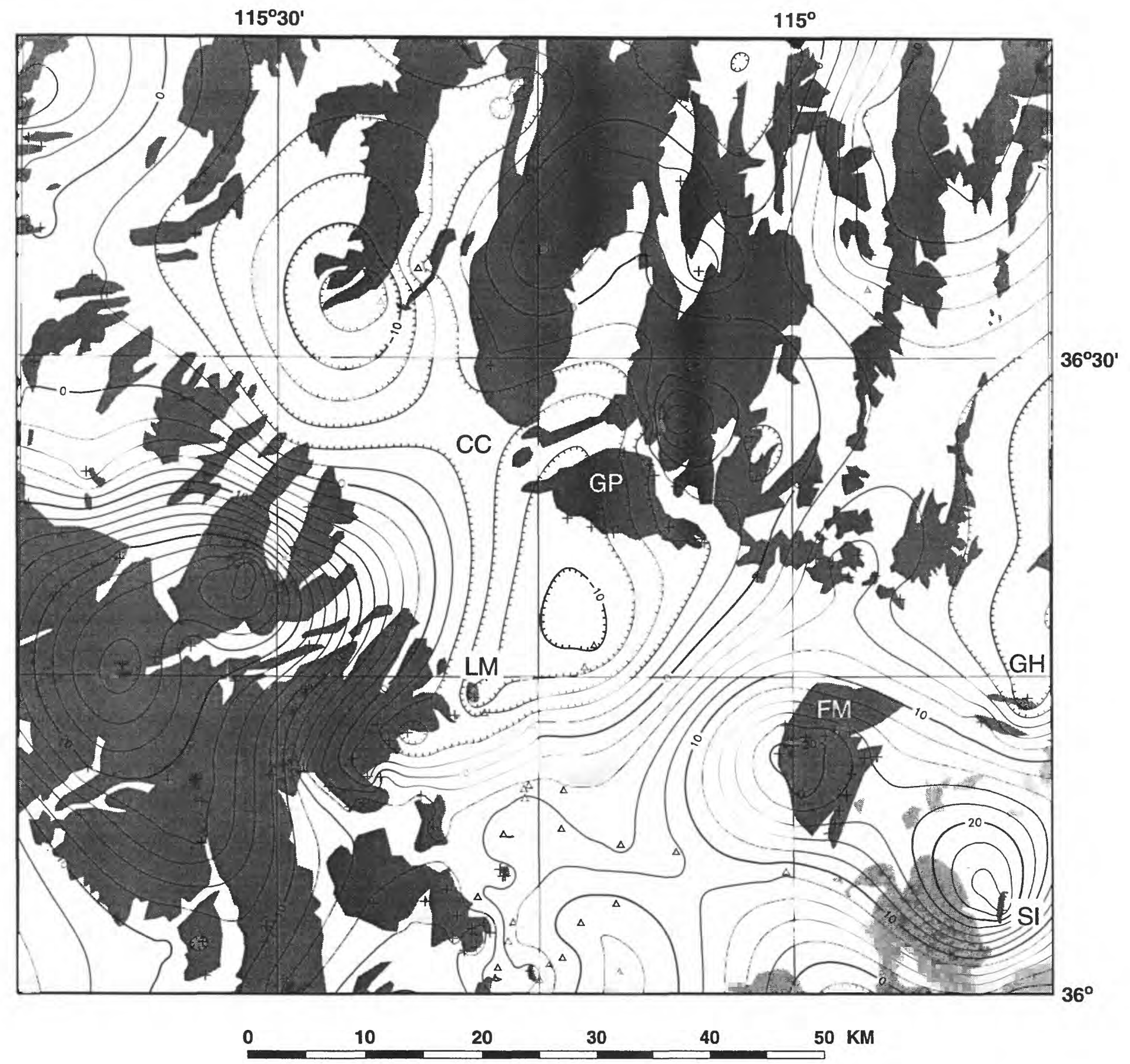

Figure $8 \mathrm{a}$. Basement gravity field. Contour interval, $2 \mathrm{mGal}$. Triangles, well and seismic control; crosses, basement gravity stations. CC, Corn Creek Springs; FM, Frenchman Mountain; GH, Gale Hills; GP, Gass Peak; LM, Lone Mountain; SI, Saddle Island. 


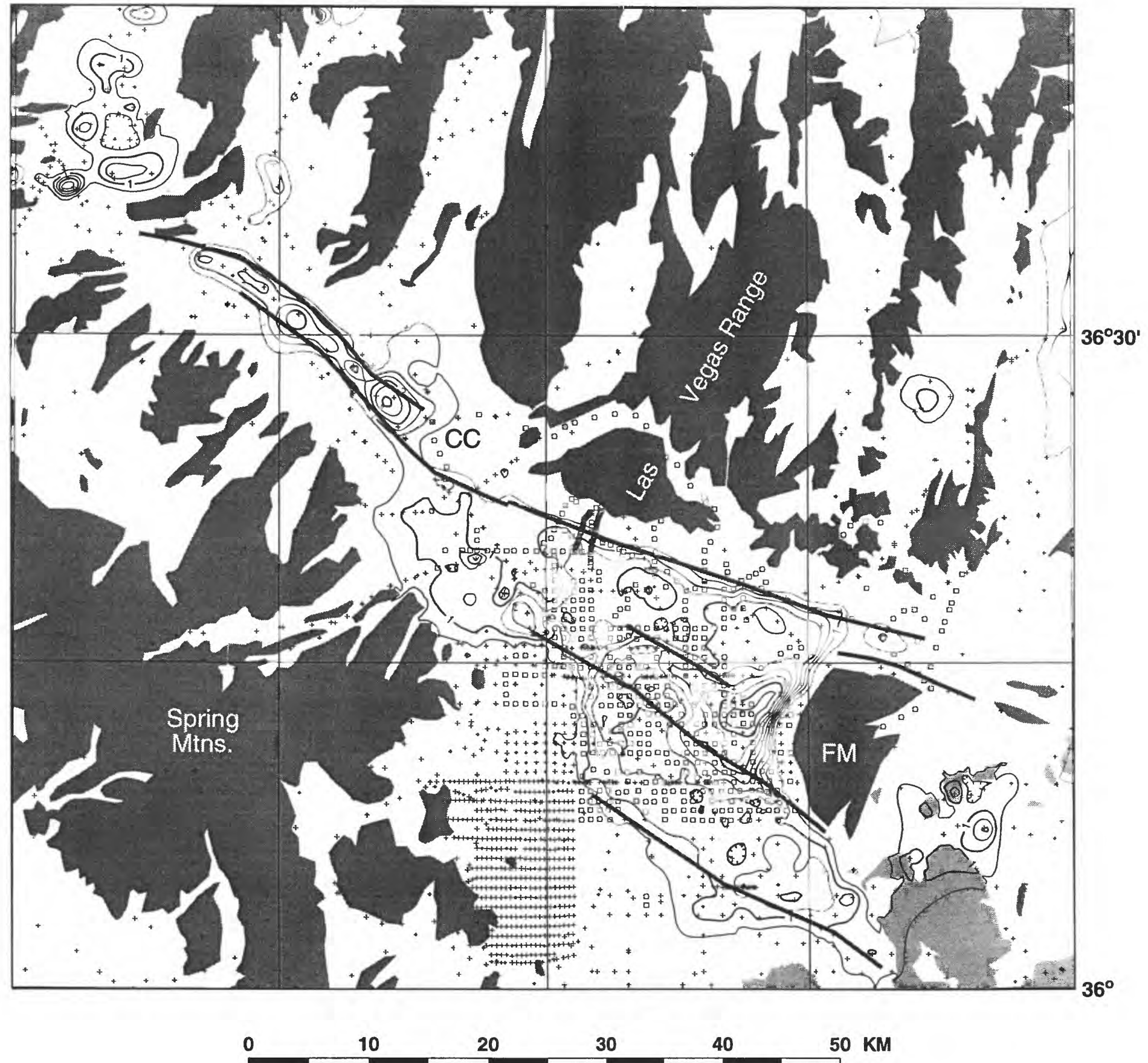

Figure $8 \mathrm{~b}$. Thickness of basin fill. Contour interval 0.5 and $1.0 \mathrm{~km}$. Dark gray lines mark possible LVVSZ strands. CC, Corn Creek Springs; FM, Frenchman Mountain. 